\title{
Effect of Potassium Fertility Levels on Gladiolus Yield Quality of Cut Flowers and Corm production
}

Muhammad Zubair

Department of Horticulture, NWFP Agricultural University, Peshawar, Pakistan

\begin{abstract}
Eight cultivars of Gladiolus "Deciso, Hong Kong, Jessica, Jester Ruffled, Madonna, Peters Pears, Rose Supreme and White Friendship” were evaluated for relative productivity in Peshawar, Pakistan over two years and at three levels of potassium $\left(0,100\right.$ and $\left.200 \mathrm{~kg} \mathrm{~K} \mathrm{ha}{ }^{-1}\right)$. There was a considerable variability in yield and quality of cut flowers as well as corm and cormels numbers in the cultivar and year with limited influence of potassium levels. Cultivars irrespective of years and potassium showed significant differences in all vegetative and floral characteristics studied during the experiment. Similarly years affected significantly all the growth parameters except first and last florets persistency and diameter of daughter corms. Potassium levels significantly affected only floret's size at full open stage, last florets persistency and number of cormels per mother corm. There was a significant interaction between years and cultivars against all growth characteristics except size of first florets at color showing as well as first and last florets persistency. A variation in the effect of potassium levels regarding number of daughter corms and cormels per mother corm of gladiolus cultivars was observed. Last florets persistency was significantly affected by an interaction among years, potassium levels and cultivars. Rose Supreme and Jessica proved superior and were recommended for commercial cultivation in Peshawar, Pakistan.
\end{abstract}

Key words: Gladiolus, Spikes, Florets, Corms, Cormels, and Potassium

\section{INTRODUCTION}

There is an interest in the production of quality cut flowers and corms of gladiolus (Gladiolus grandiflorus) in Peshawar, Pakistan for export as well as in country use. There is little information on what cultivars can be grown in Peshawar and fertility response. The different types of climatic conditions of Pakistan provide for the possibility of growing almost all the major cut flowers of the world, either from tropical, subtropical, or temperate climate origin. The present research work is aimed to explore the possibility of producing a high valued crop to replace the cultivation of poppy, to expand the employment opportunities in the area to alleviate the poverty as well as to contribute to the emerging floriculture industry in Pakistan in general and Peshawar in particular.

\section{MATERIALS AND METHODS}

The soil was analyzed for physico-chemical properties and the following information were noted: Sand (17.12 \%), silt (54\%), clay (28.88\%), pH (8.32), EC $\left(0.33 \mathrm{dSm}^{-1}\right), \mathrm{N}(100 \%$ deficient), P (27\% deficient and $73 \%$ marginal), K (50 $\%$ marginal and $50 \%$ adequate).The experiment was conducted at the Agriculture 
Research Farm, Department of Horticulture, NWFP Agricultural University, Peshawar, Pakistan during the year 2003-05. Cultivars Deciso, Hong Kong, Jessica, Jester Ruffled, Madonna, Peters Pears, Rose Supreme and White Friendship were fertilized with potassium $(\mathrm{K})$ at the rate of zero (control), 100, and $200 \mathrm{~kg} \mathrm{ha}^{-1}$. Potassium sulphate $\left(\mathrm{K}_{2} \mathrm{SO}_{4}\right.$ sulphate of potash) was used as a source for potassium. Potassium was applied before corms plantation. Welldecomposed (six months) cattle manure was mixed in the field at the rate of one ton $\mathrm{ha}^{-1}$. A basic dose of nitrogen and phosphorus was added to the field at the rate of $100 \mathrm{~kg}$ each ha ${ }^{-1}$. Phosphorus was applied before corms plantation whereas nitrogen was applied in split doses. First dose of nitrogen was applied at three-leaf stage while the second dose was applied at the time of spike emergence. All cultural practices (irrigation, weeding and spraying insecticides) were performed uniformly. The corms were imported from Netherlands. The corms were planted in a well-prepared field at a depth of $10 \mathrm{~cm}$ (Hartmann et al. 1981) in the month of November. The corms were planted in a row at a distance of $20 \mathrm{~cm}$ while the rows were made at a distance of $60 \mathrm{~cm}$. The experiment was laid out as RCBD (Randomized Complete Block Design) with split plot arrangement. The potassium levels were put in main plots whereas the cultivars were placed in subplots. The data were analyzed with the general linear model procedures in SAS (SAS Institute, ver. 6.12, Cary, N. C.), and the least significant difference (LSD) test was used for the means separation. The following growth parameters were studied:

1. Floret Size $(\mathrm{cm})$ at the Time of Color Showing (FSCS), 2. Full Opened Floret size $(\mathrm{cm})($ FSFO), 3. Spike lengths $(\mathrm{cm})$ at the Time of First Floret Opening (SLFFO), 4. Spike Lengths (cm) at Full Spike Opening (SLFSO), 5. Average number of florets spike ${ }^{-1}$ (Florets Spike ${ }^{-1}$ ), 6. Average Number of Spikes Corm ${ }^{-1}$ (Spikes Corm $^{-1}$ ), 7. First Floret Persistence (in days) (FFP), 8. Last Floret Persistence (in days) (LFP), 9. Average Number of Daughter Corms per Mother Corm (DC $\mathrm{MC}^{-1}$ ), 10. Average Number of Cormels per Mother Corm (Cormels $\left.\mathrm{MC}^{-1}\right)$, 11. Average Diameter (cm) of Daughter Corm (DDC), 12. Average Diameter (cm) of Cormels (DC).

\section{RESULTS AND DISCUSSION}

Concise analysis of variance (ANOVA) and means tables instead of giving individual ANOVAs and means tables are presented for the interpretation of results.

Before interpreting and discussing the experimental results, it is important to discuss briefly the environmental conditions prevailed during the two experimental years. High and low ambient air temperature in Celsius, soil temperature at a depth of $10 \mathrm{~cm}$ at $8.0 \mathrm{AM}$ and 5.0 PM, and precipitation in millimeters during first year (Nov. 1, 2003 to June 30, 2004) are presented in figures 1 to 3 whereas of second year (Nov. 1, 2004 to Aug. 31, 2005) in figures 4 to 6. It is observed that maximum temperature in first year and second year was decreasing from November and reached lower than $15^{\circ} \mathrm{C}$ in the month of January of first year and lower than $10^{\circ} \mathrm{C}$ in second year respectively and the minimum temperature reached $-1^{0} \mathrm{C}$ in second year. The maximum temperature again was on rise from the first week of February in first year while from the last week of February in second year. This shows that the weather was colder in second year as compared to first year (Fig. I and Fig. IV). The soil temperature in first year was 
lower than the soil temperature in second year (Fig. II and Fig. V). During the second year of the experiment, the amount and number of precipitation events were more as compared to the first year of the experiment (Fig. III and Fig. VI).

All eight cultivars were significantly different regarding vegetative and floral growth parameters (Table I and IV). Rose Supreme excelled rest of the cultivars in certain growth parameters such as spike lengths at first floret opening $(96.2 \mathrm{~cm})$ and last floret opening $(121.8 \mathrm{~cm})$, last floret persistency (5.4days), number of cormels corm ${ }^{-1}$ (136.9) and diameter of daughter corm $(7.4 \mathrm{~cm})$ (Table II and V). Jessica yielded maximum number of spikes (1.2) per corm followed by Rose Supreme (1.1), Jester Ruffled (1.1) and Deciso (1). Jessica surpassed all other cultivars in producing daughter corms (1.8) per corm (Table II and V). First floret size $(1.3 \mathrm{~cm})$ at color showing was similar in Rose Supreme and Jester Ruffled. Similarly, Rose Supreme and Deciso produced full opened florets which were not significantly different regarding size $(11.8 \mathrm{~cm}$ and $11.4 \mathrm{~cm})$ (Table II). Maximum numbers of 16.7, 16.1 and 15.6 florets per spike were observed in Rose Supreme, Jessica and Deciso respectively which were significantly different from rest of the cultivars (Table II). First florets of Rose Supreme and Jessica persisted for similar number of days (6.5) that were significantly different from other cultivars (Table V). It was observed that cultivars other than Rose Supreme, Jessica and Deciso did not have significant differences among themselves regarding certain growth parameters (Table II and V). This variability among the cultivars may be due to their different varietal characteristics. These results are similar to those of Zubair et al. (2005 and 2006) Pant et al. (1998), Aswath and Parthasarathy(1996), Patil et al. (1994) and Leena et al. (1993) who reported that certain cultivars proved superior as compared to other tested during the experiment.

Influence of year was second in significance after cultivars. Years significantly affected most of growth parameters (Table I and IV). This might be due to the prevailing environmental conditions during the two experimental years. The recorded data regarding temperature and precipitation revealed that the temperature was lower and the precipitation was more during the growing period of gladiolus in second year (Fig. I -VI). This resulted in a prolonged growing period during second year that yielded vigorous growth and better results for all growth parameters except number of daughter corms per mother corm which were maximum (1.4) in first year.








Fig. II Daily Soil temperature at a depth of $10 \mathrm{~cm}$ during 2003-04

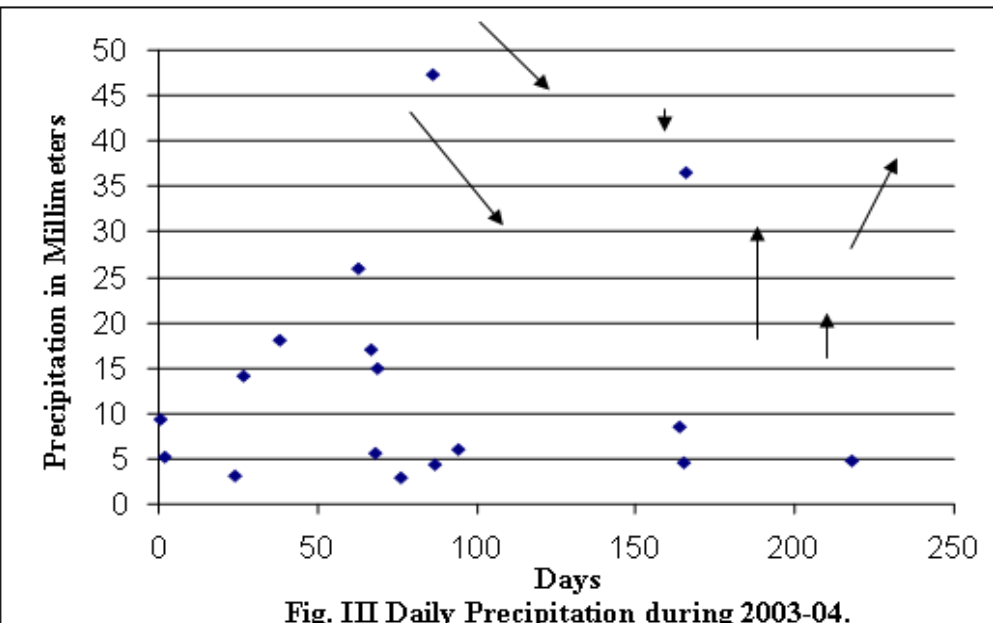

Fig. III Daily Precipitation during 2003-04.

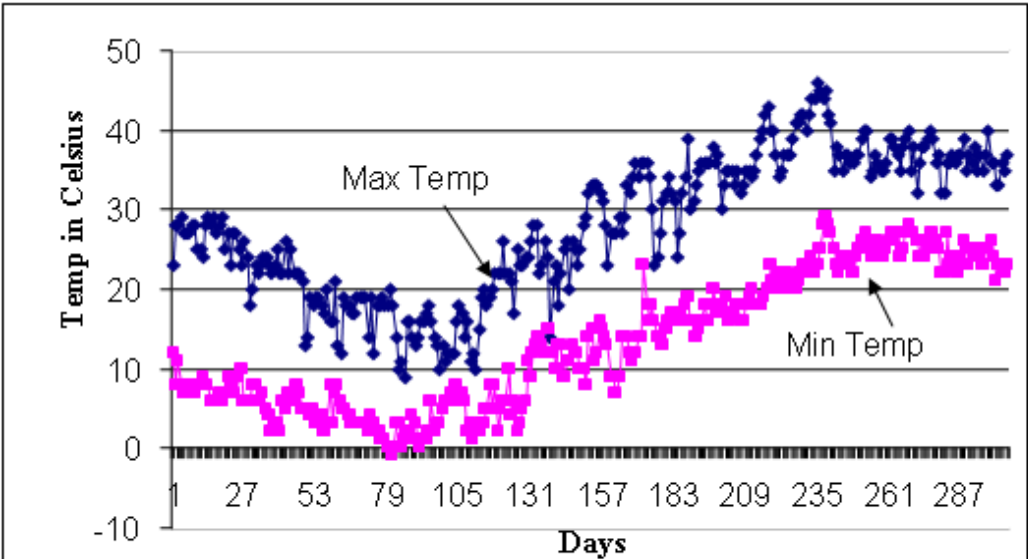

Fig. IV Daily Ambient Air Temperature during 2004-05. 

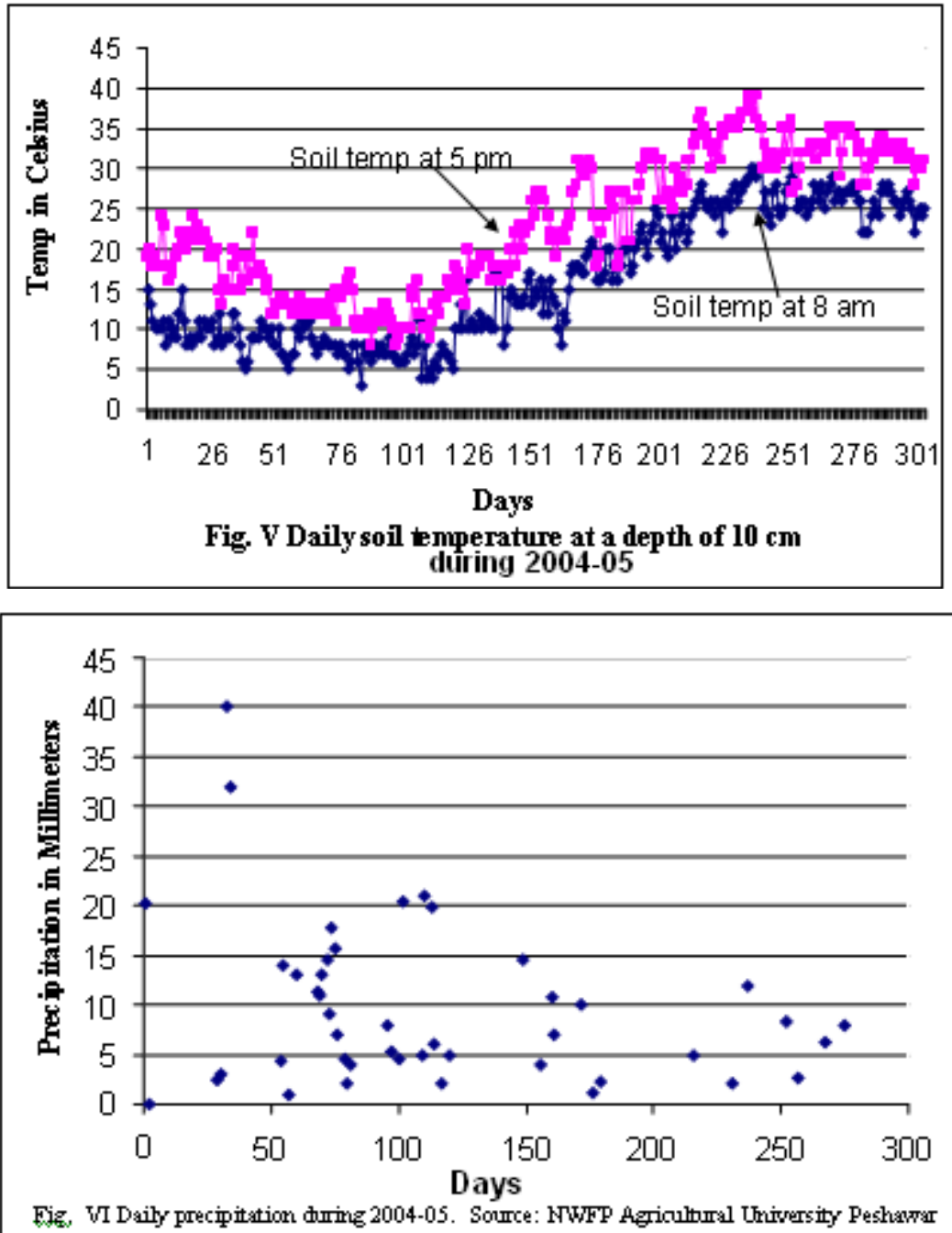

Potassium levels had a limited influence. Only the size of full opened florets, last florets persistency and number of cormels corm $^{-1}$ were affected significantly by potassium levels (Table I and VI).

Table I. Results of ANOVA on florets size both at color showing (FSCS) and full opened stage (FSFO), spike lengths both at first florets (SLFFO) and full spike opening (SLFSO), average number of florets spike ${ }^{-1}$ (Florets Spike ${ }^{-1}$ ) and spikes corm $^{-1}$ (Spikes Corm ${ }^{-1}$ ) of gladiolus cultivars fertilized with Potassium (0, 100 and $200 \mathrm{~kg} / \mathrm{ha}$ ) during 2003-04 and 2004-05.

\begin{tabular}{|l|c|c|c|c|c|c|c|}
\hline Source & DF & $\begin{array}{c}\text { FSCS } \\
(\mathrm{cm})\end{array}$ & $\begin{array}{c}\text { FSFO } \\
(\mathrm{cm})\end{array}$ & $\begin{array}{c}\text { SLFFO } \\
(\mathrm{cm})\end{array}$ & $\begin{array}{c}\text { SLFSO } \\
(\mathrm{cm})\end{array}$ & $\begin{array}{c}\text { Florets } \\
\text { Spike }^{-1}\end{array}$ & $\begin{array}{c}\text { Spikes } \\
\text { Corm }^{-1}\end{array}$ \\
\hline Model & 59 & & & & & & \\
\hline Error & 84 & & & & & & \\
\hline Corrected Total & 143 & & & & & & \\
\hline Year (Y) & 1 & $*$ & $*$ & $* *$ & $* *$ & $* *$ & $* *$ \\
\hline Rep(Year) & 4 & & & & & & \\
\hline Potassium (K) & 2 & NS & $* *$ & NS & NS & NS & NS \\
\hline Y X K & 2 & NS & NS & NS & NS & NS & NS \\
\hline Rep (Y X K) & 8 & & & & & & $*$ \\
\hline Cultivar (C) & 7 & $* *$ & $* *$ & $* *$ & $* *$ & $* *$ & $* *$ \\
\hline Y X C & 7 & NS & $* *$ & $* *$ & $* *$ & $* *$ & $* *$ \\
\hline K X C NS & 14 & NS & NS & NS & NS & NS & NS \\
\hline Y X K X C & 14 & NS & NS & NS & NS & NS & NS \\
\hline
\end{tabular}


Table II. Effect of first year (2003-04) and second year (2004-05) on FSCS, FSFO, SLFFO, SLFSO, Florets Spike ${ }^{-1}$, Spikes Corm ${ }^{-1}$ of gladiolus cultivars.

\begin{tabular}{|l|l|l|l|l|l|l|}
\hline Source & $\begin{array}{l}\text { FSCS } \\
(\mathrm{cm})\end{array}$ & $\begin{array}{l}\text { FSFO } \\
(\mathrm{cm})\end{array}$ & $\begin{array}{l}\text { SLFFO } \\
(\mathrm{cm})\end{array}$ & $\begin{array}{l}\text { SLFSO } \\
(\mathrm{cm})\end{array}$ & $\begin{array}{l}\text { Florets } \\
\text { Spike }^{-1}\end{array}$ & $\begin{array}{l}\text { Spikes } \\
\text { Corm }^{-1}\end{array}$ \\
\hline Years & \multicolumn{7}{|l|}{} \\
\hline First Year & $1.1 \mathrm{~b}$ & $10.5 \mathrm{~b}$ & $66.3 \mathrm{~b}$ & $88.6 \mathrm{~b}$ & $12.3 \mathrm{~b}$ & 0.8 \\
\hline Second Year & $1.2 \mathrm{a}$ & $10.7 \mathrm{a}$ & $85.3 \mathrm{a}$ & $103.4 \mathrm{a}$ & $16.4 \mathrm{a}$ & 0.9 \\
\hline Cultivars & \multicolumn{7}{|l|}{} \\
\hline Deciso & $1.2 \mathrm{~b}$ & $11.4 \mathrm{a}$ & $80.1 \mathrm{c}$ & $104.6 \mathrm{~b}$ & $15.6 \mathrm{ab}$ & $1.0 \mathrm{~b}$ \\
\hline Hong Kong & $1.1 \mathrm{c}$ & $10.2 \mathrm{c}$ & $69.9 \mathrm{de}$ & $85.6 \mathrm{e}$ & $12.8 \mathrm{c}$ & $0.3 \mathrm{~d}$ \\
\hline Jessica & $1.2 \mathrm{~b}$ & $10.2 \mathrm{c}$ & $68.5 \mathrm{e}$ & $88.2 \mathrm{de}$ & $16.1 \mathrm{a}$ & $1.2 \mathrm{a}$ \\
\hline Jester Ruffled & $1.3 \mathrm{a}$ & $10.9 \mathrm{~b}$ & $87.8 \mathrm{~b}$ & $106.0 \mathrm{~b}$ & $14.8 \mathrm{~b}$ & $1.1 \mathrm{ab}$ \\
\hline Madonna & $1.1 \mathrm{c}$ & $10.3 \mathrm{c}$ & $73.3 \mathrm{de}$ & $95.9 \mathrm{c}$ & $14.4 \mathrm{~b}$ & $0.4 \mathrm{~d}$ \\
\hline Peters Pears & $1.1 \mathrm{c}$ & $10.3 \mathrm{c}$ & $75.2 \mathrm{~cd}$ & $94.1 \mathrm{~cd}$ & $14.7 \mathrm{~b}$ & $0.8 \mathrm{c}$ \\
\hline Rose Supreme & $1.3 \mathrm{a}$ & $11.8 \mathrm{a}$ & $96.2 \mathrm{a}$ & $121.8 \mathrm{a}$ & $16.7 \mathrm{a}$ & $1.1 \mathrm{ab}$ \\
\hline White Friendship & $1.0 \mathrm{~d}$ & $9.6 \mathrm{~d}$ & $54.9 \mathrm{f}$ & $71.8 \mathrm{f}$ & $9.8 \mathrm{~d}$ & $0.8 \mathrm{c}$ \\
\hline LSD & 0.07 & 0.4 & 6.2 & 7.6 & 1.2 & 0.1 \\
\hline
\end{tabular}

Means with the same letter are not significantly different.

Table III. Effect of interaction (years X cultivars) on FSFO, SLFFO, SLFSO, Florets Spike ${ }^{-1}$, Spikes $\mathrm{Corm}^{-1}$ of gladiolus cultivars planted during 2003-04 and 2004-05.

\begin{tabular}{|l|l|l|l|l|l|}
\hline Source & $\begin{array}{l}\text { FSFO } \\
(\mathrm{cm})\end{array}$ & $\begin{array}{l}\text { SLFFO } \\
(\mathrm{cm})\end{array}$ & $\begin{array}{l}\text { SLFSO } \\
(\mathrm{cm})\end{array}$ & $\begin{array}{l}\text { Florets } \\
\text { Spike }^{-1}\end{array}$ & $\begin{array}{l}\text { Spikes } \\
\text { Corm }^{-1}\end{array}$ \\
\hline Years X cultivars & & & & & \\
\hline $2003-04$ X Deciso & $10.9 \mathrm{de}$ & $71.4 \mathrm{efg}$ & $93.0 \mathrm{defg}$ & $12.7 \mathrm{fg}$ & $1.0 \mathrm{bc}$ \\
\hline Hong Kong & $10.7 \mathrm{def}$ & $64.8 \mathrm{gh}$ & $82.6 \mathrm{ghi}$ & $10.1 \mathrm{hi}$ & $0.3 \mathrm{f}$ \\
\hline Jessica & $10.0 \mathrm{gh}$ & $57.5 \mathrm{hi}$ & $79.0 \mathrm{hij}$ & $14.3 \mathrm{ef}$ & $1.5 \mathrm{a}$ \\
\hline Jester Ruffled & $10.2 \mathrm{fgh}$ & $69.7 \mathrm{efgh}$ & $88.1 \mathrm{fgh}$ & $11.2 \mathrm{gh}$ & $0.4 \mathrm{ef}$ \\
\hline Madonna & $10.9 \mathrm{de}$ & $68.2 \mathrm{fg}$ & $99.0 \mathrm{cde}$ & $13.3 \mathrm{f}$ & $0.6 \mathrm{de}$ \\
\hline Peters Pears & $10.1 \mathrm{gh}$ & $66.1 \mathrm{gh}$ & $87.7 \mathrm{fgh}$ & $13.1 \mathrm{f}$ & $0.8 \mathrm{~cd}$ \\
\hline Rose Supreme & $11.2 \mathrm{~cd}$ & $81.1 \mathrm{bcd}$ & $105.3 \mathrm{c}$ & $13.4 \mathrm{f}$ & $0.8 \mathrm{~cd}$ \\
\hline White Friendship & $9.8 \mathrm{hi}$ & $51.8 \mathrm{i}$ & $74.1 \mathrm{ij}$ & $10.4 \mathrm{hi}$ & $0.9 \mathrm{bc}$ \\
\hline $2004-05$ X Deciso & $11.8 \mathrm{~b}$ & $88.9 \mathrm{~b}$ & $116.2 \mathrm{~b}$ & $18.4 \mathrm{ab}$ & $1.1 \mathrm{~b}$ \\
\hline Hong Kong & $9.7 \mathrm{hi}$ & $75.0 \mathrm{def}$ & $88.6 \mathrm{efgh}$ & $15.4 \mathrm{de}$ & $0.3 \mathrm{f}$ \\
\hline Jessica & $10.4 \mathrm{efg}$ & $80.4 \mathrm{bcd}$ & $97.5 \mathrm{cdef}$ & $18.0 \mathrm{bc}$ & $0.9 \mathrm{bc}$ \\
\hline Jester Ruffled & $11.5 \mathrm{bc}$ & $106.0 \mathrm{a}$ & $123.9 \mathrm{~b}$ & $18.4 \mathrm{ab}$ & $1.5 \mathrm{a}$ \\
\hline Madonna & $9.7 \mathrm{hi}$ & $78.3 \mathrm{cde}$ & $92.9 \mathrm{defg}$ & $15.4 \mathrm{de}$ & $0.3 \mathrm{f}$ \\
\hline Peters Pears & $10.5 \mathrm{efg}$ & $84.3 \mathrm{bc}$ & $100.6 \mathrm{~cd}$ & $16.3 \mathrm{~cd}$ & $0.8 \mathrm{~cd}$ \\
\hline Rose Supreme & $12.4 \mathrm{a}$ & $111.4 \mathrm{a}$ & $138.3 \mathrm{a}$ & $20.0 \mathrm{a}$ & $1.5 \mathrm{a}$ \\
\hline White Friendship & $9.4 \mathrm{i}$ & $58.0 \mathrm{hi}$ & $69.5 \mathrm{j}$ & $9.2 \mathrm{i}$ & $0.8 \mathrm{~cd}$ \\
\hline LSD & 0.6 & 8.7 & 10.8 & 1.7 & 0.2 \\
\hline
\end{tabular}

Means with the same letter are not significantly different.

Table IV. Results of ANOVA on first and last florets persistence (FFP, LFP respectively) in days, average number of daughter corms and cormels per mother corm (DC MC ${ }^{-1}$, Cormels $\mathrm{MC}^{-1}$ respectively), average diameter of daughter corms (DDC) and cormels (DC) in $\mathrm{cm}$ of gladiolus cultivars fertilized with potassium (0, 100 and $200 \mathrm{~kg}$ per ha) during 2003-04 and 2004-05.

\begin{tabular}{|l|l|l|l|l|l|l|l|}
\hline Source & DF & $\begin{array}{l}\text { FFP } \\
(\text { days })\end{array}$ & $\begin{array}{l}\text { LFP } \\
(\text { days })\end{array}$ & $\begin{array}{l}\text { DC } \\
\mathrm{MC}^{-1}\end{array}$ & $\begin{array}{l}\text { Cormels } \\
\mathrm{MC}^{-1}\end{array}$ & $\begin{array}{l}\text { DDC } \\
(\mathrm{cm})\end{array}$ & $\begin{array}{l}\text { DC } \\
(\mathrm{cm})\end{array}$ \\
\hline Model & 59 & & & & & & \\
\hline Error & 84 & & & & & & \\
\hline Corrected Total & 143 & & & & & & \\
\hline Year (Y) & 1 & NS & NS & $* *$ & $* *$ & NS & $* *$ \\
\hline Rep(Year) & 4 & & & & & & \\
\hline Potassium (K) & 2 & NS & $* *$ & NS & $* *$ & NS & NS \\
\hline Y X K & 2 & NS & NS & NS & NS & NS & NS \\
\hline Rep (Y X K) & 8 & & & & & & $*$ \\
\hline Cultivar (C) & 7 & $* *$ & $* *$ & $* *$ & $* *$ & $* *$ & $* *$ \\
\hline Y X C & 7 & NS & NS & $* *$ & $* *$ & $* *$ & $* *$ \\
\hline K X C & 14 & NS & NS & $*$ & $* *$ & NS & NS \\
\hline Y X K X C & 14 & NS & $*$ & NS & NS & NS & NS \\
\hline
\end{tabular}

NS, *, ** Nonsignificant or Significant at $\mathrm{P}<0.05$ or 0.01 , respectively. 
Table V. Effect of years (2003-04 and 2004-05) on FFP, LFP, DC MC ${ }^{-1}$, Cormels $\mathrm{MC}^{-1}$, DDC and DC of gladiolus cultivars.

\begin{tabular}{|c|c|c|c|c|c|c|}
\hline Source & $\begin{array}{c}\text { FFP } \\
\text { (days) }\end{array}$ & $\begin{array}{c}\text { LFP } \\
\text { (days) }\end{array}$ & $\begin{array}{c}\mathrm{DC} \\
\mathrm{MC}^{-1}\end{array}$ & $\begin{array}{c}\text { Cormels } \\
\mathrm{MC}^{-1}\end{array}$ & $\begin{array}{l}\text { DDC } \\
(\mathrm{cm})\end{array}$ & $\begin{array}{l}\mathrm{DC} \\
(\mathrm{cm})\end{array}$ \\
\hline \multicolumn{7}{|l|}{ Years } \\
\hline First Year (2003-04) & NS & NS & 1.4 & 20.0 & NS & 1.3 \\
\hline Second Year (2004-05) & NS & NS & 1.2 & 35.2 & NS & 1.5 \\
\hline \multicolumn{7}{|l|}{ Cultivars } \\
\hline Deciso & $5.2 \mathrm{bc}$ & $4.5 b c$ & $1.2 \mathrm{bcd}$ & $15.2 \mathrm{bc}$ & 5.6de & $1.4 \mathrm{~b}$ \\
\hline Hong Kong & $4.3 \mathrm{c}$ & $3.2 \mathrm{e}$ & $1.0 \mathrm{~d}$ & $9.3 \mathrm{c}$ & $5.9 \mathrm{~cd}$ & $1.8 \mathrm{a}$ \\
\hline Jessica & $6.5 \mathrm{a}$ & $4.4 \mathrm{bc}$ & $1.8 \mathrm{a}$ & $8.1 \mathrm{c}$ & 5.9cd & $1.3 \mathrm{~b}$ \\
\hline Jester Ruffled & $5.5 b$ & $4.7 \mathrm{~b}$ & $1.4 \mathrm{~b}$ & $7.7 \mathrm{c}$ & $6.2 \mathrm{bc}$ & $1.3 \mathrm{~b}$ \\
\hline Madonna & $5.3 \mathrm{~b}$ & $3.8 \mathrm{~d}$ & $1.1 \mathrm{~cd}$ & $7.6 \mathrm{c}$ & $5.2 \mathrm{e}$ & $0.9 \mathrm{c}$ \\
\hline Peters Pears & $4.9 \mathrm{bc}$ & $4.0 \mathrm{~cd}$ & $1.3 \mathrm{bc}$ & $13.2 \mathrm{bc}$ & $6.5 \mathrm{~b}$ & $1.4 \mathrm{~b}$ \\
\hline Rose Supreme & $6.5 a$ & $5.4 a$ & $1.4 \mathrm{~b}$ & $136.9 \mathrm{a}$ & $7.4 a$ & $1.7 \mathrm{a}$ \\
\hline White Friendship & $5.5 b$ & $4.5 b c$ & $1.4 \mathrm{~b}$ & $23.1 \mathrm{~b}$ & 5.6de & $1.3 \mathrm{~b}$ \\
\hline LSD & 0.9 & 0.6 & 0.2 & 10.2 & 0.5 & 0.2 \\
\hline
\end{tabular}

Means with the same letter are not significantly different.

Table VI. Effect of interaction (years X cultivars) on FFP, LFP, DC MC ${ }^{-1}$, Cormels $\mathrm{MC}^{-1}$, DDC and DC of gladiolus cultivars planted during 2003-04 and 2004-05.

\begin{tabular}{|l|l|l|l|l|}
\hline \multicolumn{1}{|c|}{ Source } & DC MC $^{-1}$ & ${\text { Cormels } \mathrm{MC}^{-1}}^{-1}$ & DDC $(\mathrm{cm})$ & DC $(\mathrm{cm})$ \\
\hline Years X Cultivars & & & & \\
\hline $2003-04$ X Deciso & $1.3 \mathrm{de}$ & $19.8 \mathrm{~cd}$ & $5.7 \mathrm{def}$ & $1.2 \mathrm{de}$ \\
\hline Hong Kong & $1.0 \mathrm{f}$ & $10.3 \mathrm{de}$ & $6.4 \mathrm{bc}$ & $2.1 \mathrm{a}$ \\
\hline Jessica & $2.0 \mathrm{a}$ & $8.6 \mathrm{de}$ & $5.8 \mathrm{cdef}$ & $1.2 \mathrm{de}$ \\
\hline Jester Ruffled & $1.1 \mathrm{ef}$ & $5.5 \mathrm{de}$ & $6.3 \mathrm{bcd}$ & $1.2 \mathrm{de}$ \\
\hline Madonna & $1.8 \mathrm{ab}$ & $11.0 \mathrm{de}$ & $5.9 \mathrm{cde}$ & $0.8 \mathrm{f}$ \\
\hline Peters Pears & $1.3 \mathrm{de}$ & $8.5 \mathrm{de}$ & $6.7 \mathrm{~b}$ & $1.3 \mathrm{cde}$ \\
\hline Rose Supreme & $1.1 \mathrm{ef}$ & $66.2 \mathrm{~b}$ & $6.4 \mathrm{bc}$ & $1.5 \mathrm{bc}$ \\
\hline White Friendship & $1.6 \mathrm{bc}$ & $30.4 \mathrm{c}$ & $5.2 \mathrm{f}$ & $1.1 \mathrm{e}$ \\
\hline 2004-05 X Deciso & $1.0 \mathrm{f}$ & $10.6 \mathrm{de}$ & $5.4 \mathrm{ef}$ & $1.6 \mathrm{~b}$ \\
\hline Hong Kong & $1.0 \mathrm{f}$ & $8.2 \mathrm{de}$ & $5.4 \mathrm{ef}$ & $1.4 \mathrm{bcd}$ \\
\hline Jessica & $1.5 \mathrm{~cd}$ & $7.6 \mathrm{de}$ & $5.9 \mathrm{cde}$ & $1.5 \mathrm{bc}$ \\
\hline Jester Ruffled & $1.8 \mathrm{ab}$ & $9.8 \mathrm{de}$ & $6.1 \mathrm{bcd}$ & $1.4 \mathrm{bcd}$ \\
\hline Madonna & $0.4 \mathrm{~g}$ & $4.1 \mathrm{e}$ & $4.5 \mathrm{~g}$ & $1.1 \mathrm{e}$ \\
\hline Peters Pears & $1.2 \mathrm{ef}$ & $18.0 \mathrm{cde}$ & $6.4 \mathrm{bc}$ & $1.5 \mathrm{bc}$ \\
\hline Rose Supreme & $1.6 \mathrm{bc}$ & $207.6 \mathrm{a}$ & $8.4 \mathrm{a}$ & $1.9 \mathrm{a}$ \\
\hline White Friendship & $1.2 \mathrm{ef}$ & $15.8 \mathrm{de}$ & $5.9 \mathrm{cde}$ & $1.5 \mathrm{bc}$ \\
\hline LSD & 0.3 & 14.4 & 0.7 & 0.2 \\
\hline
\end{tabular}

Means with the same letter are not significantly different.

Potassium at the rate of $100 \mathrm{Kg} \mathrm{ha}^{-1}$ increased the average size of full opened florets and number of cormels corm ${ }^{-1}$ (Figure VII and XI). An increase in full opened first florets might be due to the maximum turgidity (Mengel and Arneke, 1982) and loosening of cell wall materials (Hager et al. 1971) which is a prerequisite of cell expansion caused by potassium levels. Last florets persistency was increased with an increase in potassium levels (Figure VIII). It may be because of more carbohydrates present in the uppermost (last florets) of gladiolus spikes due to the continuous flow of carbohydrates from the senescing lower florets of gladiolus spikes to those developing acropetally (Waithaka et al. 2001). Bhandal and Malik (1988) as well as Mengel and Kirkby (1987) observed that potassium not only enhances the translocation of newly synthesized photosynthates but also has a beneficial effect on the mobilization of stored material and hence support the present findings. This amount of potassium might have had a beneficial effect on translocation of newly synthesized photosynthates and mobilization of stored material present in the mother corm and consequently increased the production of cormels. According to Barma et al. (1998) and Singh 
et al. (1997), cormels plant ${ }^{-1}$ was increased at $200 \mathrm{~kg} \mathrm{~K} \mathrm{ha}^{-1}$ and $30 \mathrm{gm} \mathrm{K} \mathrm{m}^{-2}$ respectively. However, Das (1998) reported non-significant results regarding cormels plant $^{-1}$ with the application of potassium.

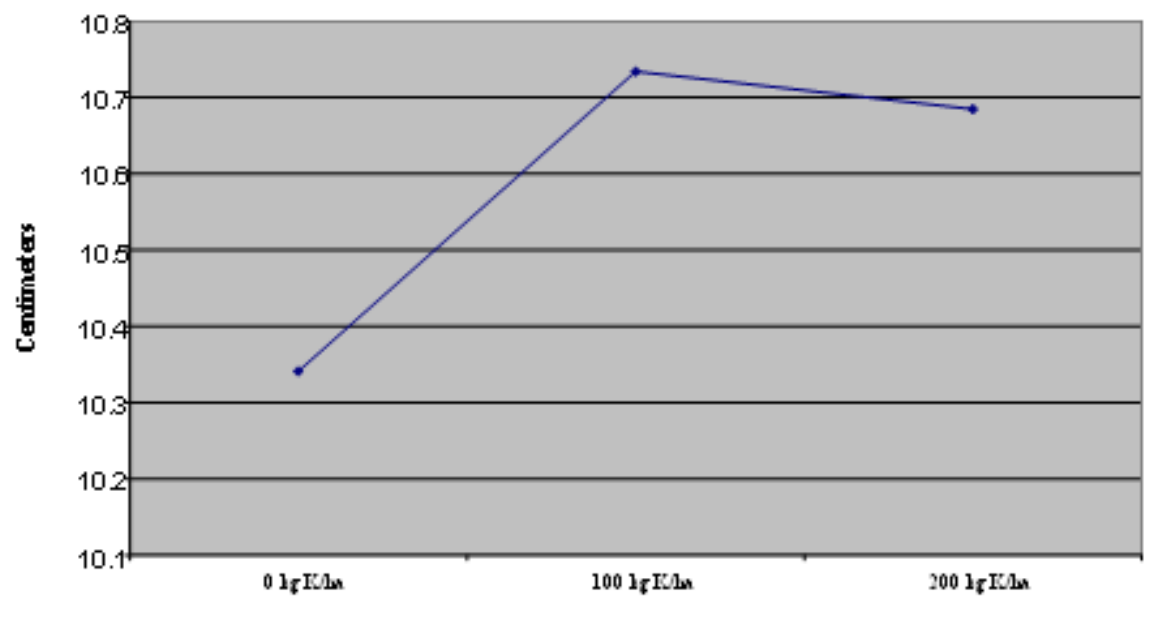

Fig VII Potassim affected sixe of the full opened florets.

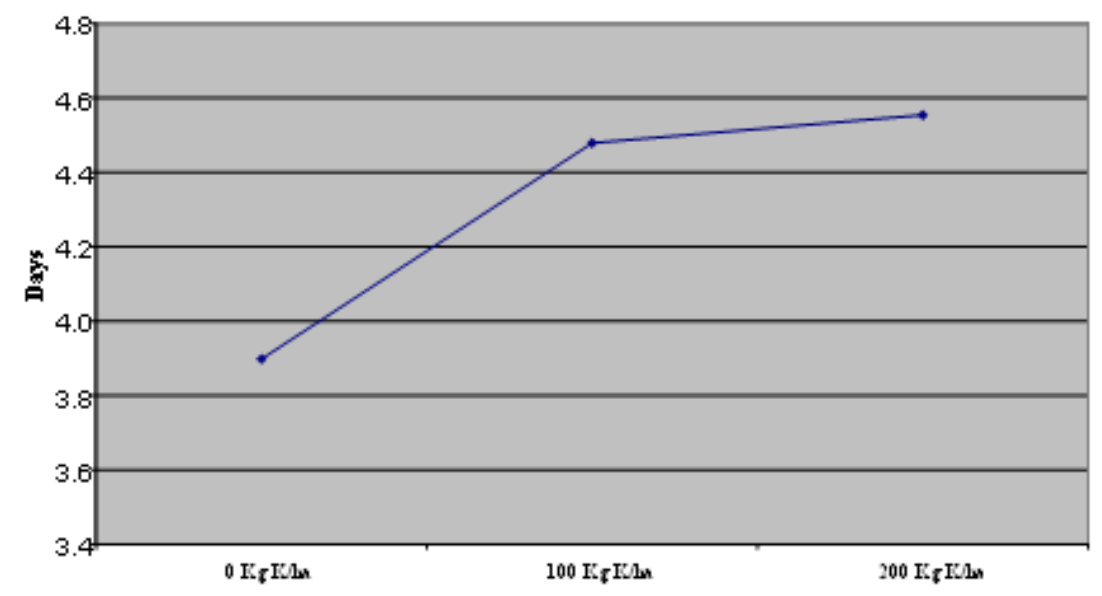

Fig. VIII Potassimn affected lastflorets persistency.








Big. $X$. Interation between potassium and cultivars sfected average number of daghter corms pe mothe coms.

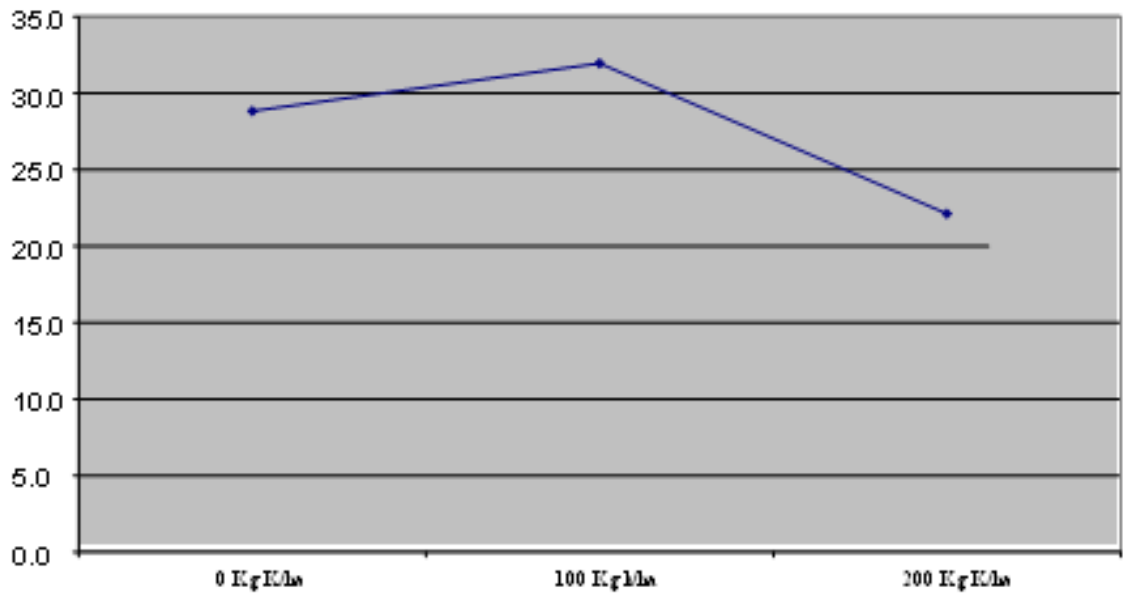

Fg. XI Potassium affected average number of counes per mother coun.

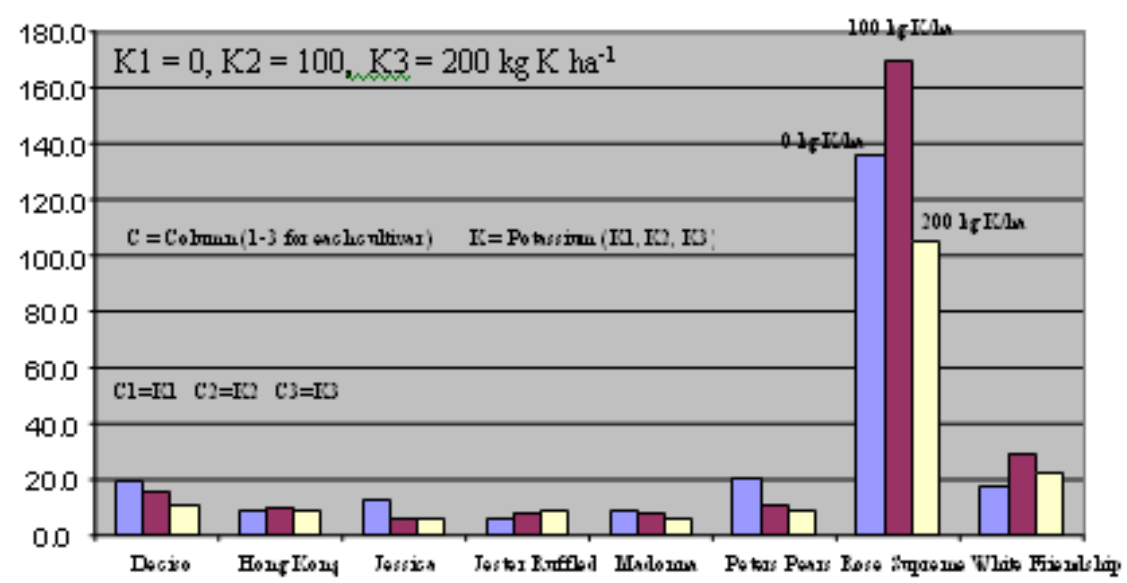

Fig. XII. Interation between potassim and culfuars affected average number of comple per mother corm.

Interaction between years and cultivars affected significantly most of the growth parameters whereas interaction between potassium and cultivars significantly affected only number of daughter corms and cormels per mother 
corm (Table I and IV). This could be due to certain genotypes whose floral characteristics are least affected by different environmental conditions.

\section{CONCLUSION AND RECOMMENDATIONS}

It is concluded from the experimental results that cultivar Rose Supreme surpassed all other cultivars under trial in most of the vegetative and floral characteristics. Jessica proved superior in producing more number of spikes and daughter corms per mother corm. Cultivars like Jester Ruffled, Deciso, Peter Pears and White Friendship yielded some convincing results and were put second in ranking after Rose Supreme and Jessica. Besides, other cultivars like Madonna and Hong Kong also performed well and yielded some good results. Hence, cultivars Rose Supreme and Jessica are recommended for commercial cultivation of gladiolus in Peshawar, Pakistan. Other tested cultivars cannot be ignored and they are also suggested for cultivation as the people look for a variety of colors. It is further advised that more numbers of cultivars need to be introduced in Peshawar. Potassium did not affect significantly most of growth characteristics under the prevailing soil and environmental conditions of Peshawar, anyhow its importance in the plant physiology cannot be ignored and it is advised that the growers should use potassium when the soil lacks it.

\section{REFERENCES}

Aouichaoui, S and Tissaoui, T. (1989). Mineral nutrition effect on the flowering of hybrid gladioli cv. grown under plastic greenhouse. Acta Hortic. No. 246, 213-218; Intern. symposium on protected cultivation of orna. in mild winter climates, Tenerife, Canary Islands, 18-21 Oct., 1988.

Aswath, C. and Parthasarathy, VA. (1996). Evaluation of gladiolus cultivars. J. Hill Research 9 (1):147-149.

Barma, G.; Chanda, S. and Roychowdhury, N. (1998). Production of corms and cormels of gladiolus through application of nitrogen, phosphorus and potassium. Hortic. J. 11(2):87- 92.

Bhandal, I. S. and Malik, C P. (1988). Potassium estimation, uptake, and its role in the physiology and metabolism of flowering plants. Intern. Review of Cytology 110:205-254.

Das, T. K. (1998). Corm and cormel production in gladiolus as affected by spike removal and K application. Ind. J. Hortic. 55(4): 327-331.

Hager, A.; Menzel, H. and Krauss, A. (1971). Experiments and hypothesis of the primary effect of auxins on expansion growth.Planta 100: 47-75.

Hartmann, H. T.; Flocker, W. J. and Kofranek, A. M. (1981). Soil and Water Management and Mineral Nutrition. In "Plant Science-Growth, Development and Utilization of Cultivated Plants” pp. 195-221.

Hartmann, H. T.; Flocker, W. J. and Kofranek, A. M. (1981). Ornamentals Grown from Bulbs, Corms, Tubers and Rhizomes. In "Plant Science- Growth, Development and Utilization of Cultivated Plants” pp. 429-453.

Leena, R.; Rajeevan, P. K. and Aravindakshan, M. (1993). Influence of the performance of selected gladiolus varieties. J. Tropical Agric. 31(2): 210214. 
Mengel, K. and Arneke, W. W. (1982). Effect of potassium on the water potential, the pressure potential, the osmotic potential and cell elongation in leaves of Phaseolus vulgaris. Physiol. Plant. 54: 402-408.

Mengel, K. and Kirkby, E. A. (1987). Photosynthesis and translocation of photosynthates. In "Principles of plant nutrition". 4th Edit. Inter. Potash Inst. Bern, Switzerland. pp. 438-440.

Pant, C. C.; Lal, S. D. and Shah, D. (1998). Performance of some gladiolus cultivars under U.P. hills conditions. Recent Hortic. 4: 73-75.

Patil, S. S. D.; Katwate, S. M.; Patil, M. T. and Patil, G. K. (1994). Performance of some exotic varieties of gladiolus. J. Maharashtra Agric. Univ. 19(1): 38-40.

Roychowdhury, N.; Roychowdhury, P.; Fjeld, T. (ed.) and Stromme, E. (1995). The effect of field application of $\mathrm{K}$ on post harvest behaviour of gladiolus. Acta Hortic. 405: 170-172.

SAS. (1989-96). The SAS System for Windows. Release 6.12. SAS Institute Inc. Cary, N.C.

Singh, K. P.; Ramachandran, N. and Uma, S. (1997). Growth, flowering, corm yield and corm-rot incidence as affected by level and frequency of potassium application in gladiolus (Gladiolus grandiflorus). Ind. J. Agric. Sci. 67(9): 404-406.

Waithaka, K.; Dodge, L. L. and Reid, M. S. (2001). Carbohydrate traffic during opening of gladiolus florets. J. Hortic. Sci. and Biotech. 76(1):120-124.

Wilfret, G. J. (1980). Gladiolus. In "Introduction to floriculture" (Larson R. A. ed.). pp. 165-181. Academic Press, Inc. New York.

Zubair, M.; Wazir, F. K. and Ayub, G. (2005). Influence of planting dates on the floral characteristics of Gladiolus under the soil and climatic conditions of Peshawar. Sarhad J. Agric. 21(4): 569-575.

Zubair, M.; Wazir, F. K.; Akhtar, S. and Ayub, G. (2006). Planting Dates affect floral characteristics under the soil and climatic conditions of Peshawar. Pak. J. Biol. Sci. 9(9): 1669-1676. 